\title{
Price Stability in Open-Economy under Inflation Targeting Regime with Factors Influencing Inflation Volatility
}

\author{
Abdelkader Aguir \\ Institute of Political Studies (IEP) Research Laboratory Public Policy, Political Action \\ Territories (PACTE) Grenoble and Faculty of Economic Sciences and Management \\ University of Sousse Unit Research: MOFID \\ E-mail: aguir_a@yahoo.fr
}

Received: October 11, 2014 Accepted: November 6, 2010 Published: November 30, 2014 doi:10.5296/ifb.v1i2.6697

URL: http://dx.doi.org/10.5296/ifb.v1i2.6697

\begin{abstract}
This paper analyzes the relevance of the inflation targeting (IT) policy in achieving its primary goal of medium term price stability in a economic emerging country experience with 'inflation targeting'. It finds that this monetary policy regime has been associated with a general reduction in inflation, principally through a reduction in inflation expectations. The question addressed in this section is to identify factors that may influence volatility of inflation and why some countries are more successful than others adopting the policy of inflation targeting.
\end{abstract}

Keywords: Price Stability, Open Economies, Inflation Targeting 


\section{Introduction}

Since the early 90s, a new monetary policy, called "inflation targeting (IT)" policy, has been adopted. It has been defined as a framework of monetary policy which consists in announcing an inflation target in advance to the public. The target level (or range) is the main argument in the central bank loss function. The central bank boards are independent in choosing the instrument to be followed in order to minimize the loss function.

This regime is characterized by (1) an explicit quantitative inflation target, either an interval or a point target, where the center of the interval or the point target currently varies across countries from 1.5 to 2.5 percent per year, (2) an operating procedure that can be described as 'inflation-forecast targeting', namely the use of an internal conditional inflation forecast as an intermediate target variable, and (3) a high degree of transparency and accountability (Note 1).

Since the early 90s, a new monetary policy, called "inflation targeting (IT)" policy, has been adopted. It has been defined as a framework of monetary policy which consists in announcing an inflation target in advance to the public. The target level (or range) is the main argument in the central bank loss function. The central bank boards are independent in choosing the instrument to be followed in order to minimize the loss function. In the IT literature, Bernanke et al. (1999) define IT in a relatively precise way as follows: "Inflation targeting is a framework for monetary policy characterized by the public announcement of official quantitative targets (or target ranges) for the inflation rate over one or more time horizons, and by explicit acknowledgement that low, stable inflation is monetary policy's primary long-run goal. Among other important features of IT are vigorous efforts to communicate with the public about plans and objectives of monetary authorities, and in many cases, mechanisms that strengthen the central bank's accountability for attaining those objectives". Another aspect of IT regime considers it as a framework of constrained discretion on the part of the central bank (Note 2).

The choice of the inflation targeting policy has been the subject of many economic controversies. Indeed, despite the convergence of literature to a successful policy of inflation targeting, the fact remains that some economists are particularly reluctant to this finding.

The debate began with the work of Leiderman \& Svensson (1995) who sought to study the impact of the adoption of inflation targeting on macroeconomic variables such as the level, persistence and inflation expectations, the cost of deflation and monetary policy.

Posen \& Mishkin (1998), Von Neumann \& Hagen (2002), Landerretche et al. (2001), Levin et al. (2004), Bernanke et al. (1999), Johnson (2002) associate the adoption of inflation targeting to a lower level of volatility and persistence of inflation and the volatility of output but also to a better anchorage inflation expectations. Roger \& Stone (2005) are associated with this assumption by showing a direct link between inflation targeting and improved economic performance. The three major findings in the literature dealing with this show:

- The level and volatility of inflation and interest rates fell after 
- The adoption of the policy of inflation targeting;

- The volatility of output has also decreased;

- The pass-through of exchange rate appears to be lower after the adoption this monetary rule.

Hyvonen (2004), Vega and Winkelried (2005) and Batini and Laxton (2007) focus meanwhile emerging economies and show that the level, persistence and the volatility of inflation is lower in countries that target inflation compared to countries that do not adopt this monetary rule.

Although these results show a significant and positive effect of the adoption of inflation targeting, these findings have been questioned by many economists (Note 3). Ball and Sheridan (2003) focus on the ambiguous effect of the adoption of inflation targeting on the performance of 20 OECD countries (including seven countries adopt this monetary policy and 13 others adopt a different policy). The authors show that inflation targeting does not make any difference in developed economies. They also raise an important point in the empirical literature on inflation targeting. Ball and Sheridan (2003) note that the choice of this monetary rule is an endogenous decision, as also pointed Gertler (2005) and Schmidt-Hebbel and Mishkin (2007). Their findings state that a performance improvement is associated with inflation targeting but that does not mean it causes this improvement.

Brito and Bystedt (2010) also show an ambiguous effect of the adoption of inflation targeting on the economic performance of emerging markets. This idea is confirmed by Von Neumann and Hagen (2002) and Siklos (1999). These authors note that the economic environment of the 90s was relatively stable and inflation followed an overall downward trend for both countries adopting inflation targeting than those not adopting this policy This debate on the effect the adoption of the policy of inflation targeting remains open.

The question addressed in this paper is to identify factors that may influence volatility of inflation and why some countries are more successful than others adopting the policy of inflation targeting.

\section{Econometric tests on the factors influencing the volatility of price.}

During the last two decades, the level and volatility of inflation fell for a number of countries. Among them were the countries with very high inflation rate as some countries of Latin America or Eastern Europe. This improvement coincided with one hand a decline in economic volatility and secondly by taking into account price stability at the heart of monetary policy.

Despite this general trend towards price stability and reform of monetary policy remain some heterogeneity between countries. Generally developed economies have a volatility much lower than emerging economies inflation.

The question addressed in this section is to identify factors that may influence the volatility of inflation and why Brasil more successful than others adopting the policy of inflation targeting. Several factors may be considered. We think of the economic and financial structure of the 
country.

Indeed, characterized by low fiscal and monetary institutions economy is facing difficulties in maintaining its inflation target.

Many economists have been interested in this debate. Pétursson (2009) identifies a number of factors that influence the volatility of inflation:

- The economic structure as the size of the economy and per capita income;

- The volatility of output;

- Exposure to external shocks such as the correlation between the global and domestic output or the correlation between private consumption and movements in the exchange rate;

- Indicators of trade such as exchange diversification or the share of domestic products in exports;

- Indicators on fluctuations in the exchange rate ie the volatility of the risk premium in the exchange rate or the degree of pass-through;

- The performance of monetary policy in the forecasts of monetary policy and the level of independence of the central bank.

Eliminating non-significant variables, Pétursson (2009) retains the indicators of fluctuations in exchange rates and performance indicators of monetary policy.

Amato \& Gerlach (2002) also study the determinants that influence inflation in the policy framework of inflation targeting. They use a probit model taking into account the structural indicators, such as trade openness ratio, a measure of credibility and other variables related to the volatility of real shocks. Schmidt-Hebbel \& Mishkin (2007) introduce different measures of independence and credibility of the central bank for a sample including a large number of countries to test their impact on inflation volatility. Carare \& Stone (2006) study certain tax and financial indicators and attempt to test whether these measures affect the stability of inflation and therefore the choice of the policy of inflation targeting. Finally, Hu (2006) uses a panel regression including a share of economic variables such as the fiscal position and secondly, institutional variables such as the independence of the central bank and a variable classification schemes exchange and finally as control variables, inflation and the growth rate of GDP.

\section{The Model}

The choice of our sample involves a restriction in some sense on the estimation method chosen. Indeed, the panel data estimates are most suitable in the case where it has a lot of people and little time data.

The advantage of using this method is that it allows to operate both the temporal and individual dimensions and taking into account the heterogeneity between those in individuals in the sample. A random effects model is proposed to try to identify the factors influencing the volatility of inflation for countries adopting the policy of inflation targeting and those 
adopting other monetary rules.

$$
I N F V O L_{i, t}=\mu+\gamma_{1} O F_{i, t}+\gamma_{2} P F_{i, t}+\gamma_{3} O C_{i, t}+\gamma_{4} P B_{i, t}+\gamma_{5} D_{i, t}+\alpha_{i}+\delta_{t}+\varepsilon_{i, t}
$$

with: $\mu$ is a constant, $Y_{i}$ with $i=1, \ldots 5$ are coefficients, $\alpha i$ is the fixed effect of country size, delta.t is the fixed effect of the time dimension and $\varepsilon i, t$ is the term error.

INFVOLi, $t$ is the volatility of inflation in country $i$ at time $t, O F i, t$ is financial openness, PFi, $t$ is financial depth, $\mathrm{OCi}, \mathrm{t}$ is the trade openness, $\mathrm{PBi}, \mathrm{t}$ is the position fiscal or budgetary and $\mathrm{Di}, \mathrm{t}$ is a dummy that takes the value 1 if the country adopts inflation targeting and 0 otherwise.

Using the estimation of a random effects model was due to the relevance of the latter with respect to a fixed effect model. Indeed, in models with fixed effects, we assume that $\alpha \mathrm{i}$ and delta.t are constant, non-random effects, which are therefore simply change the value of the constant $\mu$ depending on the values of $i$ and $t$.

While for the random-effects models, we assume that $\alpha \mathrm{i}$ and delta.t are random words and exert more effect on the constant of the model, but on the whole model.

\subsection{The Variables Used}

The study period chosen is from 1990Q1 to 2014Q2 quarterly data.

The variables used to estimate our model are mainly related to the economic and financial structure of emerging economies. Four variables are selected to describe a structural characteristics: the fiscal position, trade openness, external debt and financial depth.

\subsubsection{Fiscal Position (PBt)}

It is measured by the balance of the GDP-weighted fiscal balance. If this variable is positive, it is in the case of a surplus, if it is negative, it is a deficit. A deficit in the budget balance of the government means that the authorities will put pressure on the central bank to finance this deficit. This therefore implies a deviation from the monetary authorities of their central goal of price stability. Therefore, they adopt an expansionary monetary policy, which will cause an increase in the money supply and thus inflation. However in the case of a surplus in the budget balance, the central bank is isolated from government pressure and therefore can conduct monetary policy on price stability in an independent manner. It is then expected that the sign of the coefficient for this variable is negative. These data are mainly derived from the database International Financial Statistics in the General Government section.

\subsubsection{Commercial Opening (OCt)}

It is measured by the ratio of imports to GDP. An economy with a high degree of trade openness is exposed to the exchange rate and thus inflation. However, if the monetary authorities consider that trade openness in the implementation of the policy of inflation targeting, it can lead to a stable inflationary environment. Therefore, it is expected that the sign of this indicator is negative for countries that adopt inflation targeting. These data come 
from two different databases: International Financial Statistics.

\subsubsection{Financial Opening (OFt)}

It is approximated by the ratio of external debt in GDP. Given the unavailability of data for some countries, we adopt the approach of Lane and Milesi-Ferretti \& (2001). According to these authors, the stock of external debt is approximated by the sum of portfolio investment and other investment liabilities under the database of the International Investment .More debts the country is open financially, the more is difficult to ensure stable inflation. Therefore, it is expected that the sign of this variable is positive.

\subsubsection{Financial Depth $(\mathrm{PFt})$}

It is calculated by the ratio of M2 to GDP, which represents the degree of monetization of the economy. This variable is an important indicator of the financial system's ability to raise funds to support the economy.

Over the country has a high ratio, the greater its ability to finance deficits and therefore greater independence and the ability of monetary authorities to implement a focused price stability policy. Therefore, the expected effect of this indicator is a negative effect. These data are derived from the database of the International Financial Statistics.

The relationship between the volatility of inflation in both the tax position, financial depth and trade openness is assumed to be negative. However, this relationship is expected to positive external indebtedness.

\subsection{The Results}

Table 1 summarizes the results of the estimation of our model by the method of random effects panels. These results were classified into three periods.

The first part of the table 1 presents the estimates for all emerging economies. The second part contains only emerging economies with inflation targeting. The final period presents emerging economies without inflation targeting.

Regarding the degree of trade openness, the coefficient is negative for emerging markets. However, these coefficients are not significant.

This does not allow us to conclude with precision about the negative effect of a large trade openness on inflation volatility, in case of adoption of the policy of inflation targeting.

The variable "financial depth" is the proportion of the M2 money supply / GDP has a positive but insignificant sign. These coefficients contradict the initial hypothesis which states that the more / GDP ratio M2, the higher inflation level and variability will be low, $\mathrm{Hu}$ (2006).

Regarding the variable "Financial openness" which measures the degree of external debt, it is significant for all countries except for countries that do not target inflation.

However, it is positive for emerging markets (EmE) groups (I) and (II) also. This implies a significant positive effect of debt on the volatility of inflation in emerging markets. 
Table 1. Estimating panel data random effects

\begin{tabular}{|c|c|c|c|}
\hline & $\begin{array}{c}\text { Emerging } \\
\text { economies (I) }\end{array}$ & $\begin{array}{c}\text { Emerging economies with } \\
\text { inflation targeting (II) }\end{array}$ & $\begin{array}{c}\text { Emerging economies without inflation } \\
\text { targeting (III) }\end{array}$ \\
\hline$\mu$ & ToT EmE & ToT EmE & ToT EmE \\
\hline & $0,607^{*}$ & 0.3744 & $(1.821)$ \\
\hline $\mathrm{OF}_{\mathrm{i}, \mathrm{t}}{ }^{\mathrm{a}}$ & $(3.68)$ & $(0.3042)$ & -129721.2 \\
& $0.233^{* * *}$ & $0.2213^{* * *}$ & $(112918)$ \\
\hline $\mathrm{PF}_{\mathrm{i}, \mathrm{t}}{ }^{\mathrm{b}}$ & $(0.059)$ & $(0.0616)$ & 1.212 \\
& 0.013 & 0.0214 & $(1.312)$ \\
\hline $\mathrm{OC}_{\mathrm{i}, \mathrm{t}}{ }^{\mathrm{c}}$ & $(0.085)$ & $(0.0911)$ & -1.062 \\
& -0.055 & -0.0457 & $(1.343)$ \\
\hline $\mathrm{PB}_{\mathrm{i}, \mathrm{t}}{ }^{\mathrm{d}}$ & $(0.246)$ & $(0.2511)$ & -5.381 \\
& $-2.57^{* *}$ & $-2.662^{* *}$ & $(4.382)$ \\
\hline $\mathrm{D}_{\mathrm{i}, \mathrm{t}}{ }^{\mathrm{e}}$ & $(1.30)$ & $(1.3797)$ & - \\
& -0.219 & - & 0.1538 \\
\hline $\mathrm{R}^{2}$ & $(0.274)$ & - & 1.000 \\
\hline within & 0.0603 & 0.0629 & 0.1902 \\
\hline between & 0.7343 & 0.7176 & 60 \\
\hline overall & 0.1175 & 0.1148 & \\
\hline Nb d'observations & 196 & 136 & \\
\hline & & & \\
\hline
\end{tabular}

Note. The standard deviations of the coefficients are shown in parentheses.

$[* * *]$ : Threshold of significance at $1 \%$;

[**]: Threshold of significance at 5\%;

[*] Threshold of significance at $10 \%$;

[p]: p-value of Statistics;

[a]: financial openness;

[b] financial position;

[c]: open trade;

[d]: fiscal position;

[e]: dummy.

"Position budget" variable approximates the fiscal position of a country. The coefficient has a negative and significant at the 5\% mark. We note that for countries adopting inflation targeting, an increase of 1 million results in lower $2.66 \%$ of the volatility of inflation in emerging economies .This finding supports the initial hypothesis which states that an economy with monetary and financial institutions have developed more facilities to adopt an 
approach focused on stable inflation policy.

Indeed, a positive tax position allows the government to meet its deficit without having recourse to financing from the central bank through expansionary policies leading to greater inflation.

For countries not adopting the policy of inflation targeting, no coefficient is significant at different thresholds of $1 \%, 5 \%$ and $10 \%$.

\section{Conclusion}

The objective of this paper was to study and identify the factors influencing inflation volatility to the special characteristics of emerging markets.

The results of the second part of this paper was concluded on the one hand that the state of monetary, fiscal and financial system is an important element in the control of inflation volatility for both emerging and developed markets.

However, we note that their impact on volatility differs between groups of countries, it is obviously more important in emerging markets, which are the most vulnerable economies and therefore the most likely to have high rates of inflation.

Taking into account economic and financial characteristics such as trade openness, external debt, budget deficit and financial depth, showed the significant impact of these on volatility price. Indeed, our results showed a negative relationship for countries that adopt the policy of inflation targeting, between the surplus and inflation volatility in emerging and developed markets. This shows that if the government recorded a budget surplus, the pressure on the monetary authorities will be lower, which would allow better control of the volatility of inflation.

For the financial dependency of economies and especially the economies emerging, the results show that there is a positive relationship between external debt and inflation volatility. This is explained by the high degree of foreign currency debt of these economies and their vulnerability to changes in exchange rate that result in changes in the level of inflation.

The results of the second model also shows an ambiguous impact of trade dependence on the volatility of inflation in the case of adoption of the policy of inflation targeting and that for all countries. Regarding financial depth that reflects the ability of the financial system to mobilize funds to support the economy, we deduce that the financial system is more robust, higher the volatility of inflation tends to fall. This is true for developed economies. However, for emerging economies this link is positive reflecting the vulnerability of the financial system in those markets, which usually use the external debt in foreign currency in order to raise funds to support the economy, resulting in a significant change price levels.

\section{References}

Aguir, A. (2014). Inflation Targeting: An Alternative to Monetary Policy. International Journal of Economics and Finance, 6(7). http://dx.doi.org/10.5539/ijef.v6n7p182 
Aguir, A. (2014). The effects of inflation targeting strategy on the growing performance of emerging countries. International Journal of Economics, Commerce and Management, II(8).

Ball, L. (1998). Policy Rules for Open Economies. Research Discussion Paper 9806. Sydney: Reserve Bank of Australia. http://dx.doi.org/10.3386/w6760

Celasun, O., Gaston, G., \& Alessandro, P. (2004). Obstacles to Disinflation: What Is the Role of Fiscal Expectations? IMF Working Paper 04/111. Washington: International Monetary Fund.

Dennis, R. (2001). Monetary Policy and Exchange Rates in Small Open Economies. Federal Reserve Bank of San Francisco Economic Letter 2003-16, May. San Francisco: Federal Reserve Bank of San Francisco.

Galí, J., \& Tommaso, M. (2004). Monetary Policy and Exchange Rate Volatility in a Small Open Economy. Unpublished, Barcelona: Universitat Pompeu Fabra.

Hördahl, P., Oreste, T., \& David, V. (2003). A Joint Econometric Model of Macroeconomic and Term Structure Dynamics. Unpublished, Frankfurt: European Central Bank.

Mishkin, F. S. (2004). Can Inflation Targeting Work in Emerging Market Countries? Paper presented at an IMF conference in honor of Guillermo A. Calvo. Washington, D.C., April.

Parrado, E. (2004). Inflation Targeting and Exchange Rate Rules in an Open Economy. IMF Working Paper 04/21. Washington: International Monetary Fund.

Porter, N. (2004). Wage Compression, Employment Restrictions and Unemployment: The Case of Mauritius. IMF Working Paper 04/205. Washington: International Monetary Fund.

Porter, N., \& Yao, J. Y. (2005). Inflation Targeting Lite in Small Open Economies: The Case of Mauritius. IMF Working Paper, WP/05/172.

Rudebusch, G., \& Tao, W. (2003). A Macro-Finance Model of the Term Structure, Monetary Policy, and the Economy. Federal Reserve Bank of San Francisco Working Paper 2003-17, September. San Francisco: Federal Reserve Bank of San Francisco.

Sacerdoti, Z. E., Gamal, E. M., Padamja, K., \& Yao, Y. (2005). Mauritius: Challenges of Sustained Growth. Washington: International Monetary Fund.

Sims, C. A. (2001). Solving Linear Rational Expectations Models. Computational Economics, 20, 1-20. http://dx.doi.org/10.1023/A:1020517101123

Stone, M. (2003). Inflation Targeting Lite. IMF Working Paper 03/12. Washington: International Monetary Fund.

Svensson, L. E. O. (2000). Open Economy Inflation Targeting. Journal of International Economics, 50, 155-183. http://dx.doi.org/10.1016/S0022-1996(98)00078-6

Truman, E. (2003). Inflation Targeting and the International Financial System: Challenges and Opportunities. Washington: Institute for International Economics. 
Notes

Note 1. See, for instance, Leiderman and Svensson (1995), Haldane (1995), Haldane (1997), Mayes and Riches (1996), McCallum (1997), Svensson (1997a), Freedman (1996), and Bernanke and Mishkin (1997).

Note 2. Aguir Abdelkader (2014). The effects of inflation targeting strategy on the growing performance of emerging countries"International Journal of Economics, Commerce and Management, Vol. II, Issue 8.

Note 3. Aguir Abdelkader (2014). Inflation Targeting: An Alternative to Monetary Policy. International Journal of Economics and Finance, 6(7).

\section{Copyright Disclaimer}

Copyright for this article is retained by the author(s), with first publication rights granted to the journal.

This is an open-access article distributed under the terms and conditions of the Creative Commons Attribution license (http://creativecommons.org/licenses/by/3.0/). 